\title{
Polymorphisms in Methionine Synthase, Methionine Synthase Reductase and Serine Hydroxymethyltransferase, Folate and Alcohol Intake, and Colon Cancer Risk
}

\author{
Susan E. Steck ${ }^{a}$ Temitope Keku ${ }^{b, c}$ Lesley M. Butler ${ }^{d}$ Joseph Galanko ${ }^{b}$ \\ Beri Massa $^{\mathrm{b}}$ Robert C. Millikan ${ }^{\mathrm{b}}$ Robert S. Sandler ${ }^{\mathrm{b}, \mathrm{c}}$ \\ Departments of a Nutrition and ${ }^{b}$ Epidemiology, and ${ }^{c}$ Center for Gastrointestinal Biology and Disease, School of \\ Medicine, University of North Carolina at Chapel Hill, Chapel Hill, N.C., and d Department of Public Health Sciences, \\ University of California at Davis, Davis, Calif., USA
}

\section{Key Words}

Alcohol $\cdot$ Case-control study $\cdot$ Colon cancer $\cdot$ Folate $\cdot$ Polymorphism

\begin{abstract}
Background/Aims: We examined associations among folate and alcohol intake, single nucleotide polymorphisms (SNPs) in genes involved in one-carbon metabolism, and colon cancer risk. Methods: Colon cancer cases (294 African-Americans and 349 whites) were frequency matched to population controls (437 African-Americans and 611 whites) by age, race and sex from 33 North Carolina counties from 1996 to 2000. Folate and alcohol intakes were collected by dietary interview. Five SNPs were genotyped using DNA from whole blood: SHMT C1420T; MTRR A66G; MTR A2756G, and the previously-reported MTHFR C677T and MTHFR A1298C. Adjusted odds ratios (OR) and $95 \% \mathrm{Cl}$ were calculated using logistic regression. Results: An inverse association was observed for SHMT TT genotype as compared to CC genotype in whites $(\mathrm{OR}=0.6,95 \% \mathrm{Cl}=0.4,1.0)$, but not in African Americans. Inverse associations were observed for high folate intake in individuals carrying 0 or 1 variant allele [OR $0.2(95 \% \mathrm{Cl} 0.06$ -
\end{abstract}

0.8) for African-Americans; OR 0.2 (95\% Cl 0.1-0.6) for whites] compared to low folate intake. Modest interactions between these SNPs and alcohol or folate intakes were observed. Conclusions: Our results are consistent with other findings and provide needed data on these associations among African-Americans.

Copyright $\odot 2008$ S. Karger AG, Basel

\section{Introduction}

Low folate and high alcohol intakes are associated with an increased risk of colon cancer [1]. Folate is critical to one-carbon metabolism, acting as a coenzyme in nucleotide synthesis and DNA methylation. Folate levels may be depleted with high alcohol intake [2]. While folate has generally been thought to be safe and protective against cancer, there is evidence that it can promote the growth of preneoplastic lesions and recent work has emphasized the importance of timing and dose of folate in the carcinogenesis process [3]. In fact, investigators of a double-blind, randomized, placebo-controlled clinical trial of recurrent colorectal adenomas recently reported

\section{KARGER}

(ㄷ) 2008 S. Karger AG, Basel

Fax +4161306 1234 E-Mail karger@karger.ch www.karger.com
Dr. Susan E. Steck

Department of Epidemiology and Biostatistics, Arnold School of Public Health

University of South Carolina, 2221 Devine Street, Room 231

Columbia, SC 29208 (USA)

Tel. +1 803734 4431, Fax +1 803734 5505, E-Mail ssteck@sc.edu 
that folic acid at $1 \mathrm{mg} / \mathrm{d}$ for $6-8$ years did not reduce risk of recurrent colorectal adenoma and tended to increase the risk of advanced lesions and adenoma multiplicity [4]. Thus, investigating the mechanism of action of folate and enzymes involved in folate metabolism is important for enhancing our understanding and improving the effectiveness of our public health recommendations.

The folate metabolism pathway is complex and involves various enzymes that regulate DNA synthesis and DNA methylation. Among others, 5,10-methylenetetrahydrofolate reductase (MTHFR) is required for methylation of homocysteine to methionine [5]; serine hydroxymethyltransferase (SHMT) catalyzes the reversible conversion of serine and tetrahydrofolate to glycine and methylene tetrahydrofolate; methionine synthase (MTR) supports methionine homeostasis by catalyzing the remethylation of homocysteine to methionine in a cobalamine-dependent reaction that utilizes MTHFR as methyl donor [6]; and methionine synthase reductase (MTRR) is responsible for keeping MTR in an active form by maintaining adequate levels of activated cobalamin, the enzyme cofactor for MTR. Single nucleotide polymorphisms (SNPs) in the genes that encode these enzymes may modify the effect of folate or alcohol intake on colon cancer [7].

We previously reported associations among two polymorphisms in the MTHFR gene, folate and alcohol intake, and colon cancer risk in the North Carolina Colon Cancer Study (NCCCS) [8]. We genotyped SNPs in three additional genes encoding enzymes involved in folate metabolism, MTR, MTRR and SHMT to examine individual gene effects and joint effects with folate and alcohol intake on colon cancer risk in an ethnically diverse population. We chose these genes because they are important in folate metabolism. Our a priori hypothesis was that diet and genes would act synergistically such that individuals with the combination of high folate intake or no alcohol intake and increased number of variant alleles as defined by previous functional and epidemiologic literature would be at the lowest risk for colon cancer as compared to individuals with low folate intake or ever alcohol intake and fewer numbers of variant alleles.

\section{Materials and Methods}

The NCCCS has been described in detail previously [8]. Briefly, a case-control study of colon cancer was conducted in 33 counties in North Carolina between July 1, 1996 and June 30, 2000. Individuals with a first diagnosis of histologically confirmed invasive adenocarcinoma of the colon between July 1 ,
1996 and June 30, 2000 were identified through the rapid ascertainment system of the North Carolina Central Cancer Registry. Other case eligibility criteria included age between 40 and 85 at the time of diagnosis, residing in the 33-county study area in North Carolina, ability to give informed consent and be mentally competent to complete the interview, have a North Carolina driver's license or identification card if <age 65 (because controls<age 65 were sampled from driver's license rosters), and permission from their primary physician to participate in the study. Controls were frequency matched to cases by race, sex, and by 5 -year age group by sampling from two sources: 10 people younger than age 65 from Division of Motor Vehicle record of individuals with North Carolina driver's license or state identification cards, and 2) people age 65 and older from a list of Medicare eligible beneficiaries obtained from the Health Care Financing Administration. As described previously, for cases the contact rate (contacted participants/eligible) was $78 \%$, the cooperation rate (interviewed/eligible) was $84 \%$ and the overall response rate (product of the contact and cooperation rates) was $66 \%$. For controls, the contact rate was $90 \%$, the cooperation rate was $62 \%$ and the overall response rate was 56\% [8]. 643 colon cancer cases (294 African-Americans and 349 whites) and 1,048 population-based controls (437 African-Americans and 611 whites) were enrolled in the study.

Alcohol and folate (both dietary and supplemental) intakes were assessed using an interviewer-administered Block food frequency questionnaire that was modified slightly to include regional and ethnic foods commonly consumed in a Southern population [9]. Dietary folate was estimated from the folate content, amount, and frequency of consumption for folate-containing foods on the FFQ. Participants were asked if they took supplemental folate or multivitamins on a regular basis. Individual supplemental folate intake was estimated from the formulation of the most common over-the-counter multivitamin supplements used in the study population (400 $\mu$ g folate). Only 31 participants, or $2 \%$ cases and $2 \%$ controls, reported taking folate supplements alone (i.e. as a single vitamin, not in a multivitamin). In summary, total folate intake was defined as the sum of dietary and supplemental folate intake, as recommended by the Food and Drug Administration [10]

Blood samples were obtained from $86 \%$ of cases and $83 \%$ of controls from which DNA was extracted for genotyping. Cases and controls who provided blood samples were more likely to be male, white, and never-smokers $(\mathrm{p}<0.01)$, as previously reported [8]. No other differences between those who provided blood samples and those who did not were noted for variables such as age, education level, income, family history of colorectal cancer, or total meat intake. Five SNPs in four genes involved in the folate metabolism pathway were genotyped. The genotyping assays for the MTHFR C677T (rs1801133) and A1298C (rs1801131) polymorphisms have been described previously $[5,11]$. For the genotyping of MTRR A66G (rs1801394), MTR A2756G (rs1805087) and SHMT C1420T (rs1979277), TaqMan ${ }^{\circledR}$ probes and primers were based on the genetic sequences from the SNP500 website (www.SNP500 cancer.nci.hin.gov) and the TaqMan ${ }^{\circledR}$ assays were designed using the Applied Biosystems' Assays-by-Design ${ }^{\text {SM }}$ service. PCR reactions consisted of unlabeled PCR primers, allele-specific TaqMan ${ }^{\circledR}$ MGB probes (FAM ${ }^{\mathrm{TM}}$ and VIC ${ }^{\circledR}$ dye-labeled), $1 \times$ TaqMan $^{\circledR}$ Universal PCR Master Mix, No AmpErase ${ }^{\circledR}$ UNG, and $15 \mathrm{ng}$ of genomic DNA. PCR reactions were performed in a $15.0 \mu \mathrm{l}$ reac- 
tion volume using the Hot-Start format. PCR amplification was run on a Perkin Elmer GenAmp ${ }^{\circledR} 9700$ thermocycler using the 9600 mode under the following conditions: 1 cycle of $50.0^{\circ} \mathrm{C}$ for 2 min (AmpErase ${ }^{\circledR}$ UNG Activation), 1 cycle of $95.0^{\circ} \mathrm{C}$ for $10 \mathrm{~min}$ (AmpliTaq Gold Activation), followed by 40 cycles of $92.0^{\circ} \mathrm{C}$ for $15 \mathrm{~s}$ of denaturation and appropriate annealing temperature for $1 \mathrm{~min}$.

Genomic controls obtained from the Coriell Tissue Repository (Camden, N.J., USA) were used as positive controls. Samples that did not amplify or could not be scored were repeated. Samples that did not amplify on the second run were scored as undetermined. For quality control, a randomly selected $10 \%$ of samples were repeated. All of the $10 \%$ repeat results were found to be identical to the initial analysis. Hardy-Weinberg equilibrium was examined for each SNP using a goodness-of-fit $\chi^{2}$ test to compare the observed genotype frequencies with expected genotype frequencies based on the observed allele frequencies.

Differences between cases and controls with regard to descriptive variables and risk factors for colon cancer were compared using a t test for continuous variables and a chi-square test for categorical variables. Percentages or means \pm SEs are presented. Unconditional logistic regression was used to calculate odds ratios (ORs) and 95\% CIs using SAS statistical software version 8.0. Models presented here are adjusted for offset terms (to account for randomized recruitment scheme and to maintain the efficiency benefits of matching) related to the age, race and gender sampling probabilities [12] used to identify eligible participants. Folate intake was categorized into 'low' versus 'high' intake using the current US Dietary Reference Intake value (low is defined as less than $400 \mu \mathrm{g}$, high is defined as equal to or greater than $400 \mu \mathrm{g}$ ) as the cut-off. We also examined folate intake categorized as a tertile variable, using the 33rd and 67th percentile cut-points among control subjects only. Joint effects with genotype did not differ using the three-level folate intake variable as compared to the dichotomous variable, so only the dichotomous variable results are presented in this paper. Due to the low reported consumption of alcohol in this population, alcohol intake was defined as 'drinker' or 'nondrinker.'

We evaluated whether the joint effects represented departures from the additive and/or multiplicative model, because it has been suggested that joint effects that are less than multiplicative, but greater than additive may still be relevant, especially in terms of public health significance $[13,14]$. Joint effects of genotype and folate or alcohol intake were examined by using low folate or drinker, respectively, and the genotypes' hypothesized highest risk category (based on previous experimental and epidemiologic literature) as the common referent group and calculating ORs for each combination of folate or alcohol intake and genotype. Interaction contrast ratios (ICRs) and 95\% CIs were determined to examine additive interaction using the two-level genotype variables (homozygote wild-type vs. heterozygotes+homozygote variant) and folate or alcohol intake. ICR $>0$ is interpreted as greater than additive joint effects, ICR $<0$ is interpreted as less than additive joint effects, and ICR $=0.0$ indicates no departure from additivity. Likelihood ratio tests (LRT) were used to determine fit of the interaction term in the model to assess multiplicative interaction.

A summary SNP variable was created summing the number of variant alleles present for each SNP for each participant. In creating the summary SNP variable, we attempted to group the al- leles for each SNP according to a priori hypotheses about their functional effects and subsequent effect on cancer risk. For each gene, the variant allele was defined as the less common allele, except for MTRR 66 where previous literature suggests that the more common allele is associated with reduced risk of colon cancer, in contrast to the other gene SNPs where the more common allele has been associated with increased risk of colon cancer. Thus, for the summary variable, the following definitions of variant allele applied based on functional and epidemiologic data in the literature: MTHFR 677:T, MTHFR 1298:C, SHMT 1420:T, MTRR 66:A, and MTR 2756:G.

\section{Results}

There were 546 cases (44\% African-Americans) and 855 controls (38\% African-Americans) with complete genotyping data. Cases were slightly younger than controls (mean age cases $63.8 \pm 0.4$ vs. $65.9 \pm 0.3$ years in controls, $\mathrm{p}=0.0001)$, consumed more calories from alcohol $(\mathrm{p}=0.0009$; mean intake for cases was $64.2 \pm 8.0 \mathrm{kcal} /$ day and for controls was $35.8 \pm 3.0 \mathrm{kcal} /$ day), used NSAIDs less frequently $(\mathrm{p}=0.04$; mean was $12.6 \pm 1.2$ NSAIDS used per month for cases and $15.7 \pm 0.9$ NSAIDS used per month for controls) and tended to consume less folate on average than controls $(\mathrm{p}=0.07$; cases $=397 \pm$ 10 vs. controls $=421 \pm 8 \mu \mathrm{g} / \mathrm{day})$. The test for HardyWeinberg equilibrium was satisfied for all SNPs among both case and control subjects separately ( $p>0.10)$.

As shown in table 1, white carriers of the SHMT $1420 \mathrm{TT}$ genotype had an $\mathrm{OR}=0.6(95 \% \mathrm{CI}=0.4,1.0)$ as compared to CC carriers, while no association was observed in African-American carriers of the TT genotype $(\mathrm{OR}=1.1,95 \% \mathrm{CI}=0.6,1.8$ as compared to $C C$ carriers). No other substantial associations were observed for individual or combined genotypes and colon cancer risk.

Table 2 shows the joint effects of diet and genotype on colon cancer risk by race. For whites, high folate intake was associated with reduced risk of colon cancer among all genotypes for the individual SNPs. ICRs revealed weak departure from additivity for folate and genotypes, the only statistically significant finding was for MTRR in whites ( $p=0.01$ for ICR; $p=0.04$ for LRT evaluating multiplicative interaction). In both African-Americans and whites, the inverse association between high folate intake and colon cancer risk was strongest in those individuals with the least number of variant alleles (OR $=0.2$ and $95 \%$ CIs excluded 1.0 for both ethnic groups comparing high folate intake to low-folate intake with 0 or 1 variant alleles), and LRTs revealed borderline statistically significant departure from interaction on the multiplicative 
Table 1. Adjusted ORs and 95\% CIs for colon cancer by genotype and race

\begin{tabular}{|c|c|c|c|c|c|c|}
\hline & \multicolumn{3}{|c|}{ African-Americans } & \multicolumn{3}{|l|}{ Whites } \\
\hline & cases/controls & $\mathrm{OR}^{*}$ & $95 \% \mathrm{CI}$ & cases/controls & $\mathrm{OR}^{*}$ & $95 \% \mathrm{CI}$ \\
\hline \multicolumn{7}{|l|}{ SHMT 1420} \\
\hline $\mathrm{CC}$ & $106 / 153$ & 1.0 & ref. & $151 / 257$ & 1.0 & ref. \\
\hline $\mathrm{CT}$ & $105 / 130$ & 1.2 & $0.9,1.8$ & $128 / 205$ & 1.0 & $0.8,1.4$ \\
\hline TT & $28 / 39$ & 1.1 & $0.6,1.8$ & $28 / 71$ & 0.6 & $0.4,1.0$ \\
\hline $\mathrm{CT}, \mathrm{TT}$ & $133 / 169$ & 1.2 & $0.8,1.7$ & $156 / 276$ & 0.9 & $0.7,1.3$ \\
\hline \multicolumn{7}{|l|}{ MTRR 66} \\
\hline GG & $24 / 26$ & 1.0 & ref. & $99 / 168$ & 1.0 & ref. \\
\hline AG & $99 / 127$ & 1.0 & $0.5,1.8$ & $155 / 256$ & 1.0 & $0.8,1.4$ \\
\hline $\mathrm{AA}$ & $116 / 169$ & 0.9 & $0.5,1.6$ & $53 / 109$ & 0.8 & $0.5,1.2$ \\
\hline $\mathrm{AG}, \mathrm{AA}$ & $215 / 296$ & 0.9 & $0.5,1.7$ & $208 / 365$ & 1.0 & $0.7,1.3$ \\
\hline \multicolumn{7}{|l|}{ MTR 2756} \\
\hline $\mathrm{AA}$ & $129 / 182$ & 1.0 & ref. & $205 / 347$ & 1.0 & ref. \\
\hline AG & $94 / 125$ & 1.1 & $0.8,1.5$ & $91 / 171$ & 0.9 & $0.7,1.3$ \\
\hline GG & $16 / 15$ & 1.4 & $0.6,2.9$ & $11 / 15$ & 1.2 & $0.6,2.8$ \\
\hline AG, GG & $110 / 140$ & 1.1 & $0.8,1.6$ & $102 / 186$ & 0.9 & $0.7,1.3$ \\
\hline \multicolumn{7}{|c|}{ Number of variant alleles ${ }^{\mathrm{a}}$} \\
\hline 0 or 1 & $19 / 34$ & 1.0 & ref. & $36 / 57$ & 1.0 & ref. \\
\hline 2 or 3 & $124 / 167$ & 1.6 & $0.9,3.0$ & $172 / 255$ & 1.1 & $0.7,1.7$ \\
\hline 4 or 5 & $87 / 108$ & 1.7 & $0.9,3.3$ & $84 / 195$ & 0.7 & $0.4,1.1$ \\
\hline 6 or more & $9 / 13$ & 1.5 & $0.5,4.4$ & $15 / 26$ & 0.9 & $0.4,1.9$ \\
\hline
\end{tabular}

* Adjusted for offset terms, age, and gender.

a Includes SNPs listed in table and MTHFR C677T and A1298C; variant allele defined as follows: MTHFR 677:T; MTHFR 1298:C; SHMT 1420:T; MTRR 66:A; and MTR 2756:G.

scale ( $\mathrm{p}=0.05$ for African-Americans, $\mathrm{p}=0.04$ for whites). When dietary folate alone or folate supplement use alone was examined for interaction with genotypes, conclusions did not differ from those presented in table 2 with the exception that the LRT p-value was no longer significant for the MTRR A66G genotype among whites ( $\mathrm{p}=$ 0.10 for dietary folate only and $\mathrm{p}=0.43$ for supplemental folate only).

For African-Americans, reduced risk of colon cancer was observed for never drinkers with the SHMT CC genotype, and for ever drinkers with the SHMT TT genotype, although neither of these associations was statistically significant (table 3 ). The ICR $>0.5$ suggested greater than additive effects ( $p=0.002$ for ICR) and the LRT suggested greater than multiplicative interaction $(\mathrm{p}=0.04)$. There was no evidence for interaction among whites. Due to small numbers, many of the estimates were imprecise when stratified by race.

Polymorphisms, Folate and Alcohol Intake, and Colon Cancer

\section{Discussion}

We examined the associations among colon cancer and SNPs in genes encoding three enzymes involved in the folate metabolism pathway, SHMT, MTRR and MTR, based on functional changes of these SNPs and previous reports of associations with colon cancer. With the exception of a borderline statistically significant decreased risk of colon cancer in whites with the SHMT TT genotype as compared to the CC genotype, we found no association between the individual SNPs studied and colon cancer risk. In combined gene analyses, which also included two previously reported SNPs in the MTHFR gene, the inverse association between folate intake and colon cancer was strongest among those individuals with the least number of variant alleles for both African-Americans and whites which was contrary to our a priori hypothesis of greatest reduced risk among those with the most number of variant alleles and high folate intake.

J Nutrigenet Nutrigenomics 2008;1:196-204 
Table 2. Joint effects of individual and combined SNPs and folate intake on colon cancer risk by race

\begin{tabular}{|c|c|c|c|c|c|c|c|c|c|c|c|c|}
\hline & \multicolumn{6}{|c|}{ African-Americans } & \multicolumn{6}{|l|}{ Whites } \\
\hline & \multicolumn{3}{|c|}{ low folate $<400 \mu \mathrm{g}$} & \multicolumn{3}{|c|}{ high folate $\geq 400 \mu \mathrm{g}$} & \multicolumn{3}{|c|}{ low folate $<400 \mu \mathrm{g}$} & \multicolumn{3}{|c|}{ high folate $\geq 400 \mu \mathrm{g}$} \\
\hline & $\begin{array}{l}\text { cases/ } \\
\text { controls }\end{array}$ & $\mathrm{OR}^{*}$ & $95 \%$ CI & $\begin{array}{l}\text { cases/ } \\
\text { controls }\end{array}$ & $\mathrm{OR}^{*}$ & $95 \% \mathrm{CI}$ & $\begin{array}{l}\text { cases/ } \\
\text { controls }\end{array}$ & $\mathrm{OR}^{*}$ & $95 \%$ CI & $\begin{array}{l}\text { cases/ } \\
\text { controls }\end{array}$ & $\mathrm{OR}^{*}$ & $95 \% \mathrm{CI}$ \\
\hline \multicolumn{13}{|l|}{ SHMT 1420} \\
\hline $\mathrm{CC}$ & $72 / 93$ & 1.0 & ref. & $31 / 54$ & 0.7 & $0.4,1.2$ & $94 / 121$ & 1.0 & ref. & $53 / 129$ & 0.5 & $0.3,0.8$ \\
\hline $\mathrm{CT}$ & $67 / 85$ & 1.0 & $0.7,1.7$ & $34 / 42$ & 1.0 & $0.6,1.8$ & $68 / 97$ & 0.9 & $0.6,1.3$ & $57 / 100$ & 0.7 & $0.5,1.1$ \\
\hline $\mathrm{TT}$ & $19 / 27$ & 0.9 & $0.4,1.7$ & $8 / 12$ & 0.9 & $0.3,2.3$ & $13 / 32$ & 0.5 & $0.3,1.1$ & $15 / 37$ & 0.5 & $0.2,0.9$ \\
\hline $\mathrm{CT}, \mathrm{TT}$ & $86 / 112$ & 1.0 & $0.7,1.5$ & $42 / 54$ & 1.0 & $0.6,1.7$ & $81 / 129$ & 0.8 & $0.5,1.2$ & $72 / 137$ & 0.7 & $0.4,1.0$ \\
\hline & \multicolumn{6}{|c|}{$\begin{array}{l}\text { ICR }=0.34(95 \% \text { CI }-0.29,0.96), p=0.29 \\
\text { LRT } p=0.29\end{array}$} & \multicolumn{6}{|c|}{$\begin{array}{l}\text { ICR }=0.33(95 \% \text { CI }-0.05,0.71), p=0.09 \\
\text { LRT } p=0.13\end{array}$} \\
\hline \multicolumn{13}{|l|}{ MTRR 66} \\
\hline GG & $16 / 19$ & 1.0 & ref. & $7 / 7$ & 1.0 & $0.3,3.8$ & $63 / 74$ & 1.0 & ref. & $34 / 91$ & 0.4 & $0.2,0.7$ \\
\hline$A G$ & $67 / 78$ & 1.2 & $0.5,2.5$ & $27 / 44$ & 0.8 & $0.3,1.8$ & $82 / 126$ & 0.8 & $0.5,1.2$ & $69 / 121$ & 0.7 & $0.4,1.0$ \\
\hline $\mathrm{AA}$ & $75 / 108$ & 1.0 & $0.4,2.0$ & $39 / 57$ & 0.9 & $0.4,2.1$ & $30 / 50$ & 0.7 & $0.4,1.2$ & $22 / 54$ & 0.5 & $0.3,0.9$ \\
\hline \multirow[t]{2}{*}{ AG, AA } & $142 / 186$ & 1.0 & $0.5,2.2$ & $66 / 101$ & 0.9 & $0.4,1.8$ & $112 / 176$ & 0.7 & $0.4,1.1$ & $91 / 175$ & 0.6 & $0.4,0.9$ \\
\hline & \multicolumn{6}{|c|}{$\begin{array}{l}\text { ICR }=-0.24(95 \% \mathrm{CI}-1.71,1.23), \mathrm{p}=0.75 \\
\text { LRT } p=0.71\end{array}$} & \multicolumn{6}{|c|}{$\begin{array}{l}\text { ICR }=0.44(95 \% \text { CI } 0.09,0.78), p=0.01 \\
\text { LRT } p=0.04\end{array}$} \\
\hline \multicolumn{13}{|l|}{ MTR 2756} \\
\hline AA & $87 / 114$ & 1.0 & ref. & $36 / 62$ & 0.7 & $0.4,1.2$ & $121 / 164$ & 1.0 & ref. & $82 / 168$ & 0.6 & $0.5,0.9$ \\
\hline AG & $64 / 81$ & 1.0 & $0.7,1.6$ & $28 / 41$ & 0.9 & $0.5,1.6$ & $48 / 80$ & 0.8 & $0.5,1.3$ & $39 / 89$ & 0.6 & $0.4,0.9$ \\
\hline GG & $7 / 10$ & 0.8 & $0.3,2.3$ & $9 / 5$ & 2.0 & $0.6,6.4$ & $6 / 6$ & 1.3 & $0.4,4.3$ & $4 / 9$ & 0.6 & $0.2,2.1$ \\
\hline \multirow[t]{2}{*}{ AG, GG } & $71 / 91$ & 1.0 & $0.7,1.5$ & $37 / 46$ & 0.7 & $0.6,1.7$ & $54 / 86$ & 0.9 & $0.6,1.3$ & $43 / 98$ & 0.6 & $0.4,0.9$ \\
\hline & \multicolumn{6}{|c|}{$\begin{array}{l}\text { ICR }=0.29(95 \% \text { CI }-0.36,0.95), p=0.38 \\
\text { LRT } p=0.36\end{array}$} & \multicolumn{6}{|c|}{$\begin{array}{l}\mathrm{ICR}=0.07(95 \% \mathrm{CI}-0.39,0.53), \mathrm{p}=0.77 \\
\mathrm{LRT} p=0.89\end{array}$} \\
\hline \multicolumn{13}{|c|}{ Number of variant alleles ${ }^{a}$} \\
\hline 0 or 1 & $15 / 18$ & 1.0 & ref. & $4 / 15$ & 0.2 & $0.1,0.8$ & $26 / 24$ & 1.0 & ref. & $9 / 31$ & 0.2 & $0.1,0.6$ \\
\hline 2 or 3 & $81 / 107$ & 1.0 & $0.4,2.1$ & $36 / 55$ & 0.8 & $0.4,1.9$ & $99 / 114$ & 0.8 & $0.4,1.4$ & $69 / 134$ & 0.5 & $0.2,0.8$ \\
\hline 4 or 5 & $58 / 70$ & 1.1 & $0.5,2.3$ & $28 / 36$ & 1.0 & $0.4,2.3$ & $43 / 98$ & 0.4 & $0.2,0.8$ & $39 / 89$ & 0.4 & $0.2,0.8$ \\
\hline 6 or more & $4 / 10$ & 0.5 & $0.1,2.0$ & $5 / 2$ & $3.4^{\mathrm{b}}$ & $0.6,20.3$ & $7 / 14$ & 0.5 & $0.2,1.3$ & $8 / 12$ & 0.5 & $0.2,1.6$ \\
\hline & \multicolumn{6}{|c|}{ LRT $p=0.05$} & \multicolumn{6}{|c|}{ LRT $p=0.04$} \\
\hline
\end{tabular}

\footnotetext{
* Adjusted for offset terms, age, and gender.

${ }^{a}$ Includes SNPs listed in table and MTHFR C677T and A1298C; variant allele defined as follows: MTHFR 677:T; MTHFR 1298:C; SHMT 1420:T; MTRR 66:A; and MTR 2756:G.

$\mathrm{b}$ This OR is based on extremely small numbers and, thus, is an unstable estimate.
}

Genetic polymorphisms in genes that encode key enzymes in the folate pathway, such as MTHFR, SHMT, $M T R R$ and MTR, may contribute to colon cancer risk. Functional polymorphisms in these genes may alter the availability of folate for DNA synthesis and methylation, and consequently influence susceptibility to cancer. Functional changes associated with SNPs in these folate metabolizing genes have been reported [7], though the data are limited for most. In one study, SHMT 1420 CC genotype carriers were found to have reduced plasma fo- late, reduced red cell folate and increased plasma homocysteine compared to TT carriers [15], though no such associations were found in another study [16]. For the MTR $2756 \mathrm{~A}>\mathrm{G}$ polymorphism, decreased homocysteine levels have been found for the GG genotype as compared to the AA genotype in some studies [17-19], but not all [20-22]. For MTRR A66G, some studies have reported elevated homocysteine levels for carriers of the homozygote wild-type genotype (AA) as compared to other genotypes [23, 24], while others have not [25]. More research 
Table 3. Joint effects of individual and combined SNPs and alcohol intake on colon cancer risk by race

\begin{tabular}{|c|c|c|c|c|c|c|c|c|c|c|c|c|}
\hline & \multicolumn{6}{|c|}{ African-Americans } & \multicolumn{6}{|l|}{ Whites } \\
\hline & \multicolumn{3}{|l|}{ drinker } & \multicolumn{3}{|c|}{ nondrinker } & \multicolumn{3}{|l|}{ drinker } & \multicolumn{3}{|c|}{ nondrinker } \\
\hline & $\begin{array}{l}\text { cases/ } \\
\text { controls }\end{array}$ & $\mathrm{OR}^{*}$ & $95 \% \mathrm{CI}$ & $\begin{array}{l}\text { cases/ } \\
\text { controls }\end{array}$ & $\mathrm{OR}^{*}$ & $95 \% \mathrm{CI}$ & $\begin{array}{l}\text { cases/ } \\
\text { controls }\end{array}$ & $\mathrm{OR}^{*}$ & $95 \%$ CI & $\begin{array}{l}\text { cases/ } \\
\text { controls }\end{array}$ & $\mathrm{OR}^{*}$ & $95 \% \mathrm{CI}$ \\
\hline \multicolumn{13}{|l|}{ SHMT 1420} \\
\hline $\mathrm{CC}$ & $22 / 18$ & 1.0 & ref. & $81 / 129$ & 0.5 & $0.3,1.1$ & $52 / 102$ & 1.0 & ref. & $95 / 148$ & 1.3 & $0.9,2.0$ \\
\hline $\mathrm{CT}$ & $23 / 30$ & 0.6 & $0.3,1.5$ & $78 / 98$ & 0.7 & $0.4,1.5$ & $57 / 79$ & 1.4 & $0.9,2.3$ & $68 / 118$ & 1.2 & $0.7,1.9$ \\
\hline $\mathrm{TT}$ & $4 / 12$ & 0.3 & $0.1,1.0$ & $23 / 27$ & 0.8 & $0.3,1.8$ & $10 / 27$ & 0.7 & $0.3,1.6$ & $18 / 42$ & 0.8 & $0.4,1.6$ \\
\hline \multirow[t]{2}{*}{ CT, TT } & $27 / 42$ & 0.5 & $0.2,1.2$ & $101 / 125$ & 0.7 & $0.4,1.5$ & $67 / 106$ & 1.2 & $0.8,2.0$ & $86 / 160$ & 1.1 & $0.7,1.7$ \\
\hline & \multicolumn{6}{|c|}{$\begin{array}{l}\text { ICR }=0.66(95 \% \text { CI } 0.24,1.08), p=0.002 \\
\text { LRT } p=0.04\end{array}$} & \multicolumn{6}{|c|}{$\begin{array}{l}\mathrm{ICR}=-0.50(95 \% \mathrm{CI}-1.28,0.28), \mathrm{p}=0.21 \\
\text { LRT } \mathrm{p}=0.15\end{array}$} \\
\hline \multicolumn{13}{|l|}{ MTRR 66} \\
\hline GG & $4 / 3$ & 1.0 & ref. & $19 / 23$ & 0.7 & $0.1,3.7$ & $37 / 65$ & 1.0 & ref. & $60 / 100$ & 1.1 & $0.7,1.9$ \\
\hline AG & $30 / 32$ & 0.9 & $0.2,4.3$ & $64 / 91$ & 1.7 & $0.1,3.3$ & $64 / 96$ & 1.2 & $0.7,2.0$ & $87 / 151$ & 1.1 & $0.7,1.8$ \\
\hline $\mathrm{AA}$ & $15 / 25$ & 0.6 & $0.1,3.0$ & $99 / 140$ & 1.7 & $0.1,3.4$ & $18 / 47$ & 0.7 & $0.3,1.4$ & $34 / 57$ & 1.1 & $0.6,2.0$ \\
\hline \multirow[t]{2}{*}{ AG, AA } & $45 / 57$ & 0.7 & $0.2,3.6$ & $163 / 231$ & 0.7 & $0.2,3.3$ & $82 / 143$ & 1.0 & $0.6,1.7$ & $121 / 208$ & 1.1 & $0.7,1.7$ \\
\hline & \multicolumn{6}{|c|}{$\begin{array}{l}\text { ICR }=0.26(95 \% \text { CI }-0.99,1.51), p=0.68 \\
\text { LRT } p=0.73\end{array}$} & \multicolumn{6}{|c|}{$\begin{array}{l}\text { ICR }=-0.06(95 \% \text { CI }-0.74,0.61), p=0.86 \\
\text { LRT } p=0.85\end{array}$} \\
\hline \multicolumn{13}{|l|}{ MTR 2756} \\
\hline AA & $32 / 40$ & 1.0 & ref. & $91 / 136$ & 0.9 & $0.5,1.7$ & $79 / 137$ & 1.0 & ref. & $124 / 195$ & 1.1 & $0.8,1.6$ \\
\hline AG & $16 / 18$ & 1.3 & $0.5,2.9$ & $76 / 105$ & 1.0 & $0.6,1.8$ & $37 / 66$ & 1.0 & $0.6,1.6$ & $50 / 103$ & 0.9 & $0.6,1.4$ \\
\hline GG & $1 / 2$ & 0.6 & $0.1,7.0$ & $15 / 13$ & 1.4 & $0.6,3.5$ & $3 / 5$ & 1.1 & $0.2,4.7$ & $7 / 10$ & 1.3 & $0.5,3.6$ \\
\hline \multirow[t]{2}{*}{$\mathrm{AG}, \mathrm{GG}$} & $17 / 20$ & 1.2 & $0.5,2.7$ & $91 / 118$ & 1.1 & $0.6,1.8$ & $40 / 71$ & 1.0 & $0.6,1.6$ & $57 / 113$ & 0.9 & $0.6,1.4$ \\
\hline & \multicolumn{6}{|c|}{$\begin{array}{l}\mathrm{ICR}=-0.08(95 \% \mathrm{CI}-1.09,0.94), \mathrm{p}=0.88 \\
\text { LRT } \mathrm{p}=0.90\end{array}$} & \multicolumn{6}{|c|}{$\begin{array}{l}\text { ICR }=-0.19(95 \% \text { CI }-0.83,0.46), p=0.57 \\
\text { LRT } p=0.57\end{array}$} \\
\hline \multicolumn{13}{|c|}{ Number of variant alleles ${ }^{\mathrm{a}}$} \\
\hline 0 or 1 & $4 / 5$ & 1.0 & ref. & $15 / 28$ & 0.7 & $0.1,3.0$ & $8 / 16$ & 1.0 & ref. & $27 / 39$ & 1.4 & $0.5,3.7$ \\
\hline 2 or 3 & $32 / 30$ & 1.5 & $0.4,6.3$ & $85 / 132$ & 1.0 & $0.3,4.1$ & $68 / 113$ & 1.2 & $0.5,2.9$ & $100 / 135$ & 1.5 & $0.6,3.7$ \\
\hline 4 or 5 & $10 / 22$ & 0.7 & $0.1,3.2$ & $76 / 85$ & 1.3 & $0.3,5.3$ & $39 / 66$ & 1.2 & $0.5,3.0$ & $43 / 121$ & 0.7 & $0.3,1.8$ \\
\hline \multirow[t]{2}{*}{6 or more } & $3 / 3$ & 1.4 & $0.2,11.8$ & $6 / 9$ & 1.1 & $0.2,6.0$ & $4 / 13$ & 0.6 & $0.3,2.3$ & $11 / 13$ & 1.7 & $0.5,5.4$ \\
\hline & \multicolumn{6}{|c|}{ LRT $p=0.23$} & \multicolumn{6}{|c|}{ LRT $p=0.06$} \\
\hline
\end{tabular}

\footnotetext{
* Adjusted for offset terms, age, and gender.

a Includes SNPs listed in table and MTHFR C677T and A1298C; variant allele defined as follows: MTHFR 677:T; MTHFR 1298:C; SHMT 1420:T; MTRR 66:A; and MTR 2756:G.
}

is needed regarding the functional effects of SNPs in these genes as related to effects on folate metabolism and subsequent folate availability.

Other epidemiologic studies have found associations between some of these individual SNPs and colon cancer risk, though few studies have examined these in African Americans. The MTHFR 677 TT and the 1298CC genotypes individually are associated with reduced risk of colon cancer in the majority of studies to date [26] and reviewed in [7]. Lowest risk has been found among those with both MTHFR 677TT and 1298CC genotypes [8]. For MTRR A66G, an increased risk of colorectal cancer was observed among Japanese with the $G G$ genotype compared to $A A+A G$ referent [27], and another study found increased risk with the $G G$ genotype among white subjects only [28]. Results of studies of the MTR $2756 \mathrm{G}$ allele and colon cancer or colorectal adenoma have been inconsistent [7,27-29], and recent analyses of the Nurses Health Study and Health Professionals Follow-up Study found a nonsignificant increased risk of 
colorectal cancer for variant allele carriers of this SNP [30].

We observed a modest inverse association for carriers of the homozygous SHMT C1420T variant genotype among whites. In two prospective cohort studies of colorectal cancer, no association was reported with the SHMT genotype [16]. The difference between our finding and the previous finding could reflect physiological differences in the effects of folate metabolism in the colon versus the rectum. For example, an inverse association between the MTHFR C677T genotype has also been reported for colon, but not rectal cancer [31].

We did not observe an association among AfricanAmericans for SHMT C1420T genotype and colon cancer. Consistent with this finding, we previously reported an inverse association for the MTHFR 1298CC genotype and colon cancer among whites, but no association among African-Americans [8]. Differences in folate metabolism between African-Americans and whites, other than those due to variation in the measured genes, may explain lack of an association between SHMT and colon cancer among African-Americans in our study. This hypothesis is supported by findings from a nutritional study in a controlled environment, where African-American women had statistically significant lower folate blood and urine levels, compared to non-Hispanic white and Hispanic women, regardless of MTHFR genotype or folate intake [32].

There is evidence that associations between some folate-metabolizing enzyme genes and colon cancer are observed only in the context of folate or alcohol intake [33]. We were able to examine joint effects of folate or alcohol intake and genotype on colon cancer risk by race, but were limited by small cell sizes when examining the interaction between these gene-diet exposures. For example, our finding of an inverse association among AfricanAmerican drinkers with the SHMT TT genotype was based on only 4 cases, and therefore highly imprecise and likely to be spurious.

A limitation of our study was the opportunity for misclassification of dietary exposures. It is possible that nondifferential recall of folate-containing foods biased our joint effects odds ratios toward the null. Our study design limited the opportunity for misclassification of dietary exposures by using a modified version of an 150 item, validated food-frequency questionnaire that was administered in-person by trained interviewers. Slight modifications to the previously validated FFQ were made to include foods consumed by a Southern population [9] and these additions were not validated. How- ever, these modifications most likely had minimal or no effect on assessment of folate or alcohol intakes. Vitamin supplement use was evaluated as a source of folate intake, and we estimated the amount of folate intake from individual folate supplements from the formulation of the most common over-the-counter multivitamin supplements used in the study population (400 $\mu \mathrm{g}$ folate). Given the small number of participants who reported consuming individual folate supplements ( $2 \%$ of cases and controls), this is unlikely to have biased our results substantially. In addition, we examined the gene-folate interactions using only dietary sources of folate intake and in separate analyses, using only folate supplement use, and our results did not change substantially from those presented here.

Because many genes are involved in folate metabolism, the effect of multiple functional polymorphisms in genes encoding for enzymes in the pathway may be expected to be stronger than the effect of any one individual polymorphism. However, we found no strong evidence for this in our combined analyses by summing number of variant alleles and comparing the highest category of variant alleles to the lowest. Other studies have examined different combinations of folate-metabolizing enzyme genes including the methylene tetrahydrofolate dehydrogenase (MTHFDI), glutamate carboxypeptidase II (GC$P I I)$, thymidylate syntase (TS), and reduced folate carrier (RFC) genes [16, 34, 35] which were not studied here, but no clear patterns have emerged. Koushik et al. reported associations for 24 SNPs in thirteen genes involved in one-carbon metabolism and colorectal cancer risk, and found associations for MTHFR C677T, MTRR Ser284Thr, MTRR Arg415Cys as well as joint effects for MTR Asp919Gly and TCN II Pro259Arg [30]. Large populations are required to examine these gene-gene and gene-nutrient interactions using traditional epidemiologic methods. New methods of mathematical modeling developed for this pathway may provide insight into the effects of modifying components of the system to inform future studies [36]. Additional studies are needed to replicate our findings in different racial/ethnic groups and improve our ability to predict the effects of polymorphisms within genes in one-carbon metabolism and folate status on colon cancer risk. 


\section{Acknowledgements}

This research was supported in part by grants from the National Institutes of Health (P30 DK34987, R01 66635, and 1K07CA102640). Dr. Butler was supported by National Institute of Child Health and Human Development's Building Interdisci- plinary Research Careers in Women's Health (BIRCWH) grant 5K12HD051958. These analyses were conducted while Dr. Steck was an American Institute for Cancer Research/World Cancer Research Fund Marilyn Gentry Fellow at the University of North Carolina at Chapel Hill.

\section{References}

1 Slattery ML, Boucher KM, Caan BJ, Potter JD, Ma KN: Eating patterns and risk of colon cancer. Am J Epidemiol 1998;148:4-16.

2 Little J, Sharp L, Duthie S, Narayanan S: Colon cancer and genetic variation in folate metabolism: the clinical bottom line. J Nutr 2003;133:3758S-3766S

3 Ulrich CM, Potter JD: Folate supplementation: too much of a good thing? Cancer Epidemiol Biomarkers Prev 2006;15:189-193.

4 Cole BF, Baron JA, Sandler RS, Haile RW, Ahnen DJ, Bresalier RS, McKeown-Eyssen G, Summers RW, Rothstein RI, Burke CA, Snover DC, Church TR, Allen JI, Robertson DJ, Beck GJ, Bond JH, Byers T, Mandel JS, Mott LA, Pearson LH, Barry EL, Rees JR, Marcon N, Saibil F, Ueland PM, Greenberg ER: Folic acid for the prevention of colorectal adenomas: a randomized clinical trial. JAMA 2007;297:2351-2359.

5 Rady PL, Szucs S, Grady J, Hudnall SD, Kellner LH, Nitowsky H, Tyring SK, Matalon RK: Genetic polymorphisms of methylenetetrahydrofolate reductase (MTHFR) and methionine synthase reductase (MTRR) in ethnic populations in Texas: a report of a novel MTHFR polymorphic site, G1793A. Am J Med Genet 2002;107:162-168.

6 Olteanu H, Banerjee R: Human methionine synthase reductase, a soluble $\mathrm{P}-450$ reductase-like dual flavoprotein, is sufficient for $\mathrm{NADPH}$-dependent methionine synthase activation. J Biol Chem 2001;276:3555835563.

7 Sharp L, Little J: Polymorphisms in genes involved in folate metabolism and colorectal neoplasia: a HuGE review. Am J Epidemiol 2004;159:423-443.

8 Keku T, Millikan R, Worley K, Winkel S, Eaton A, Biscocho L, Martin C, Sandler R: 5,10Methylenetetrahydrofolate reductase codon 677 and 1,298 polymorphisms and colon cancer in African-Americans and whites. Cancer Epidemiol Biomarkers Prev 2002;11: 1611-1621.

9 Gerber AM, James SA, Ammerman AS, Keenan NL, Garrett JM, Strogatz DS, Haines PS: Socioeconomic status and electrolyte intake in black adults: the Pitt County Study. Am J Publ Health 1991;81:1608-1612.
10 Lewis CJ, Crane NT, Wilson DB, Yetley EA: Estimated folate intakes: data updated to reflect food fortification, increased bioavailability, and dietary supplement use. Am J Clin Nutr 1999;70:198-207.

11 Weisberg I, Tran P, Christensen B, Sibani S, Rozen R: A second genetic polymorphism in methylenetetrahydrofolate reductase (MTHFR) associated with decreased enzyme activity. Mol Genet Metab 1998;64 169-172.

12 Weinberg CR, Sandler DP: Randomized recruitment in case-control studies. Am J Epidemiol 1991;134:421-432.

13 Greenland S, Poole C: Invariants and noninvariants in the concept of interdependent effects. Scand J Work Environ Health 1988; 14: 125-129.

14 Millikan R: The changing face of epidemiology in the genomics era. Epidemiology 2002; 13:472-480.

15 Heil SG, Van der Put NM, Waas ET, den Heijer M, Trijbels FJ, Blom HJ: Is mutated serine hydroxymethyltransferase (SHMT) involved in the etiology of neural tube defects? Mo Genet Metab 2001;73:164-172.

16 Chen J, Kyte C, Valcin M, Chan W, Wetmur JG, Selhub J, Hunter DJ, Ma J: Polymorphisms in the one-carbon metabolic pathway, plasma folate levels and colorectal cancer in a prospective study. Int J Cancer 2004; 110:617-620

17 Chen J, Stampfer MJ, Ma J, Selhub J, Malinow MR, Hennekens $\mathrm{CH}$, Hunter DJ: Influence of a methionine synthase (D919G) polymorphism on plasma homocysteine and folate levels and relation to risk of myocardial infarction. Atherosclerosis 2001;154: 667-672.

18 Harmon DL, Shields DC, Woodside JV, McMaster D, Yarnell JW, Young IS, Peng K, Shane B, Evans AE, Whitehead AS: Methionine synthase $\mathrm{D} 919 \mathrm{G}$ polymorphism is a significant but modest determinant of circulating homocysteine concentrations. Genet Epidemiol 1999;17:298-309.

19 Fredriksen A, Meyer K, Ueland PM, Vollset SE, Grotmol T, Schneede J: Large-scale population-based metabolic phenotyping of thirteen genetic polymorphisms related to one-carbon metabolism. Hum Mutat 2007; 28:856-865.
20 van der Put NM, van der Molen EF, Kluijtmans LA, Heil SG, Trijbels JM, Eskes TK, Van Oppenraaij-Emmerzaal D, Banerjee R, Blom HJ: Sequence analysis of the coding region of human methionine synthase: relevance to hyperhomocysteinaemia in neuraltube defects and vascular disease. QJM 1997; 90:511-517.

21 Ma J, Stampfer MJ, Christensen B, Giovannucci E, Hunter DJ, Chen J, Willett WC, Selhub J, Hennekens CH, Gravel R, Rozen R: A polymorphism of the methionine synthase gene: association with plasma folate, vitamin $\mathrm{B}_{12}$, homocyst(e)ine, and colorectal cancer risk. Cancer Epidemiol Biomarkers Prev 1999;8:825-829.

22 Jacques PF, Bostom AG, Selhub J, Rich S, Ellison RC, Eckfeldt JH, Gravel RA, Rozen R: Effects of polymorphisms of methionine synthase and methionine synthase reductase on total plasma homocysteine in the NHLBI Family Heart Study. Atherosclerosis 2003; 166:49-55

23 Gaughan DJ, Kluijtmans LA, Barbaux S, McMaster D, Young IS, Yarnell JW, Evans A, Whitehead AS: The methionine synthase reductase (MTRR) A66G polymorphism is a novel genetic determinant of plasma homocysteine concentrations. Atherosclerosis 2001;157:451-456.

24 Geisel J, Zimbelmann I, Schorr H, Knapp JP, Bodis M, Hubner U, Herrmann W: Genetic defects as important factors for moderate hyperhomocysteinemia. Clin Chem Lab Med 2001;39:698-704.

25 O'Leary VB, Parle-McDermott A, Molloy AM, Kirke PN, Johnson Z, Conley M, Scott JM, Mills JL: MTRR and MTHFR polymorphism: link to Down syndrome? Am J Med Genet 2002;107:151-155.

26 Le Marchand L, Wilkens LR, Kolonel LN, Henderson BE: The MTHFR C677T polymorphism and colorectal cancer: the multiethnic cohort study. Cancer Epidemiol Biomarkers Prev 2005;14:1198-1203.

27 Matsuo K, Hamajima N, Hirai T, Kato T, Inoue M, Takezaki T, Tajima K: Methionine synthase reductase gene A66G polymorphism is associated with risk of colorectal cancer. Asian Pac J Cancer Prev 2002;3:353359. 
28 Le Marchand L, Donlon T, Hankin JH, Kolonel LN, Wilkens LR, Seifried A: B-vitamin intake, metabolic genes, and colorectal cancer risk (United States). Cancer Causes Control 2002;13:239-248.

29 Goode EL, Potter JD, Bigler J, Ulrich CM: Methionine synthase D919G polymorphism, folate metabolism, and colorectal adenoma risk. Cancer Epidemiol Biomarkers Prev 2004;13:157-162.

30 Koushik A, Kraft P, Fuchs CS, Hankinson SE, Willett WC, Giovannucci EL, Hunter DJ: Nonsynonymous polymorphisms in genes in the one-carbon metabolism pathway and associations with colorectal cancer. Cancer Epidemiol Biomarkers Prev 2006;15:24082417.
31 Jiang Q, Chen K, Ma X, Li Q, Yu W, Shu G, Yao K: Diets, polymorphisms of methylenetetrahydrofolate reductase, and the susceptibility of colon cancer and rectal cancer. Cancer Detect Prev 2005;29:146-154.

32 Perry CA, Renna SA, Khitun E, Ortiz M, Moriarty DJ, Caudill MA: Ethnicity and race influence the folate status response to controlled folate intakes in young women. J Nutr 2004;134:1786-1792.

33 Larsson SC, Giovannucci E, Wolk A: A prospective study of dietary folate intake and risk of colorectal cancer: modification by caffeine intake and cigarette smoking. Cancer Epidemiol Biomarkers Prev 2005; 14:740743.
34 Martin S, Ulrich C, Munsell M, Taylor S, Lange G, Bleyer A: Delays in cancer diagnosis in underinsured young adults and older adolescents. Oncologist 2007;12:816-824.

35 Curtin K, Ulrich CM, Samowitz WS, Bigler J, Caan B, Potter JD, Slattery ML: Thymidylate synthase polymorphisms and colon cancer: associations with tumor stage, tumor characteristics and survival. Int J Cancer 2007;120:2226-2232.

36 Reed MC, Nijhout HF, Neuhouser ML, Gregory JF 3rd, Shane B, James SJ, Boynton A, Ulrich CM: A mathematical model gives insights into nutritional and genetic aspects of folate-mediated one-carbon metabolism. J Nutr 2006; 136:2653-2661. 